\title{
Analysis of road traffic injuries in Mexican cyclists
}

\author{
Victoria Alejandra Muro-Báez¹, M. Eulalia Mendoza-García², Juan Daniel Vera-López³ and \\ Ricardo Pérez-Núñez ${ }^{4}$ \\ ${ }^{1}$ Sociology Undergraduate Student; ${ }^{2}$ Sociology Graduate; ${ }^{3} \mathrm{MSc}$ in Health Sciences; ${ }^{4} \mathrm{PhD}$ in Public Health Sciences, Secretariado Técnico del
} Consejo Nacional para la Prevención de Accidentes, Secretaría de Salud México, Mexico City, Mexico

\begin{abstract}
With the objective of analyzing fatal and non-fatal road traffic injuries in cyclists and to document helmet use in this road user to inform sustainable mobility policies, a descriptive analysis of four secondary official information sources was conducted at the national level: mortality, Ministry of Health's hospital discharges, Unintentional and Violence Registry System (SIS-SS-17-P) and the 2012 National Health and Nutrition Survey (ENSANUT). Only SIS-SS-17-P and ENSANUT document helmet use. Except for ENSANUT, information analyzed is of 2014. A total of 190 cyclists died in Mexico during 2014 and 392 were hospitalized; the head was the anatomical region most frequently affected (63\% and $32 \%$, respectively). Only $0.75 \%$ of the 667 cases registered in SIS-17 reported helmet use and 24\% suffered head injuries. Of the 165,348 non-fatally injured cyclists from ENSANUT $<10 \%$ used helmet, $24 \%$ had head injuries and more than 16,000 suffered permanent injuries. Whereas cyclist-friendly infrastructure is an effective intervention to prevent injuries in the long term, helmet use could potentially reduce the frequency and severity of head injuries in the short run, while bicycle use widespread as a means of transportation providing "safety in numbers".
\end{abstract}

KEY WORDS: Road traffic injuries. Cyclists. Helmet. Injuries.

\section{Introduction}

According to the World Health Organization, 1.25 million deaths are attributed to road traffic injuries (RTI) every year, with $4 \%$ of these corresponding to cyclists, which means that around 50,000 cyclists die annually from this cause all over the the world. This percentage has been documented to likely be higher in some low and middle-income countries'. Cyclists are considered to be vulnerable road users, since they are not protected by a physical structure, which exposes them to sustain more severe injuries in case of a traffic event or even to die when suffering a collision. This is relevant because cyclists share public roads with quickly-moving private automobiles and freight or passenger transport vehicles. In contexts where the use of bicycle is not very common or where it has been promoted only recently, cyclists are often poorly visible to motor vehicle drivers ${ }^{2}$.

Recently, public policies intended to foster more sustainable mobility have been promoted in Mexico. One of them is the use of bicycle as a transportation means in different parts of the national territory, through systems of public bicycles. For example, the ECOBICI system $^{3}$ in Mexico City, implemented since February 2010, which currently has 444 bicycle stations, more than 6000 bicycles and more than 100,000 daily users, covering a $35-\mathrm{km}^{2}$ area; the $\mathrm{MIBICl}$ system ${ }^{4}$ in the city of Guadalajara, since December 2014, which currently has 116 bicycle stations (located at the central areas of Guadalajara and Zapopan) and 1160 bicycles; the SmartBike ${ }^{5}$ public bicycle system pilot test in the city of Puebla, which from November 2013 and until September 2015 considered a 5.6-kilometer quadrant of

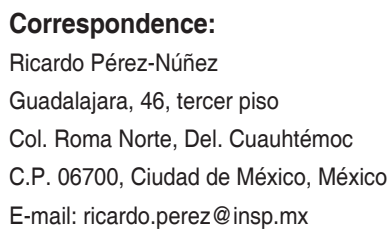

Date of reception: 20-07-2016

Date of acceptance: 08-08-2016

DOI://dx.doi.org/10.24875/GMM.M18000052
Gac Med Mex. 2017;153:588-595

Contents available at PubMed www.gacetamedicademexico.com 
the historic center, with 6 bicycle stations and 81 bicycles; and finally, the implementation of the Huizi ${ }^{6}$ public bicycle system of the city of Toluca, which has 26 bicycle stations across 218 blocks of the city's downtown area and 350 bicycles. Taken as a whole, according to the Institute for Transportation and Development Policy (ITDP). In the 30 largest cities of the country there is a national registry of 477 kilometers of cycling infrastructure, equivalent to $0.8 \mathrm{~km}$ per 100,000 population, out of which $20 \%$ are one-way cycle paths, $20 \%$ bicycle lanes, $58 \%$ two-way cycle paths and $2 \%$ shared lanes (public transport and bicycle) $)^{7}$.

The increased use of bicycle and the insertion of public bicycle systems in urban areas motivate the present study, which seeks to make a diagnosis of the main damages to health experienced by cyclists as a result of RTIs. In addition, the use of helmet as a safety device is explored in this population group. We consider this analysis will allow the follow-up of these mobility public measures and the establishment of specific actions that guarantee for this mobility to develop in a context of road safety for these vulnerable users.

\section{Methods}

This is a cross-sectional study that uses nation-wide secondary sources to identify the sociodemographic profile of cyclists with fatal and non-fatal injuries sustained while circulating in public roads, as well as the most common type of injury. For this purpose, four sources of information were used:

- The entire 2014 mortality database, jointly generated by the Ministry of Health and the National Institute of Statistics and Geography ${ }^{8}$.

- The 2014 Ministry of Health hospital discharge database, which concentrates around $50 \%$ of the country's hospital discgharges ${ }^{9}$.

- 2014 information of the statistical system "SISSS-17-P Hoja de Registro de Atención por Violencia y/o Lesión" (a form to be filled when care is provided in cases related to acts of violence and/or injuries otherwise sustained), which is mainly used in Ministry of Health units ${ }^{10}$.

- The 2012 National Health and Nutrition Survey (ENSANut-2012 - Encuesta Nacional de Salud y Nutrición 2012) which is representative of the country and was conducted by the National Institute of Public Health"1.

For the purposes of this study, a cyclist was defined as any injured subject recorded and classified with the following International Statistical Classification of Diseases and Health-related Problems, $10^{\text {th }}$ revision (ICD-10) codes: V10 (.3-.9), V11 (.03-.09), V12 (.3-.9), V13 (.3-.9), V14 (.3-.9) and V19 (.4-.6) $)^{12}$

A descriptive analysis of the main variables of interest for this work was carried out with STATA-13 ${ }^{\circledR}$.

Table 1. Available variables according to source of information

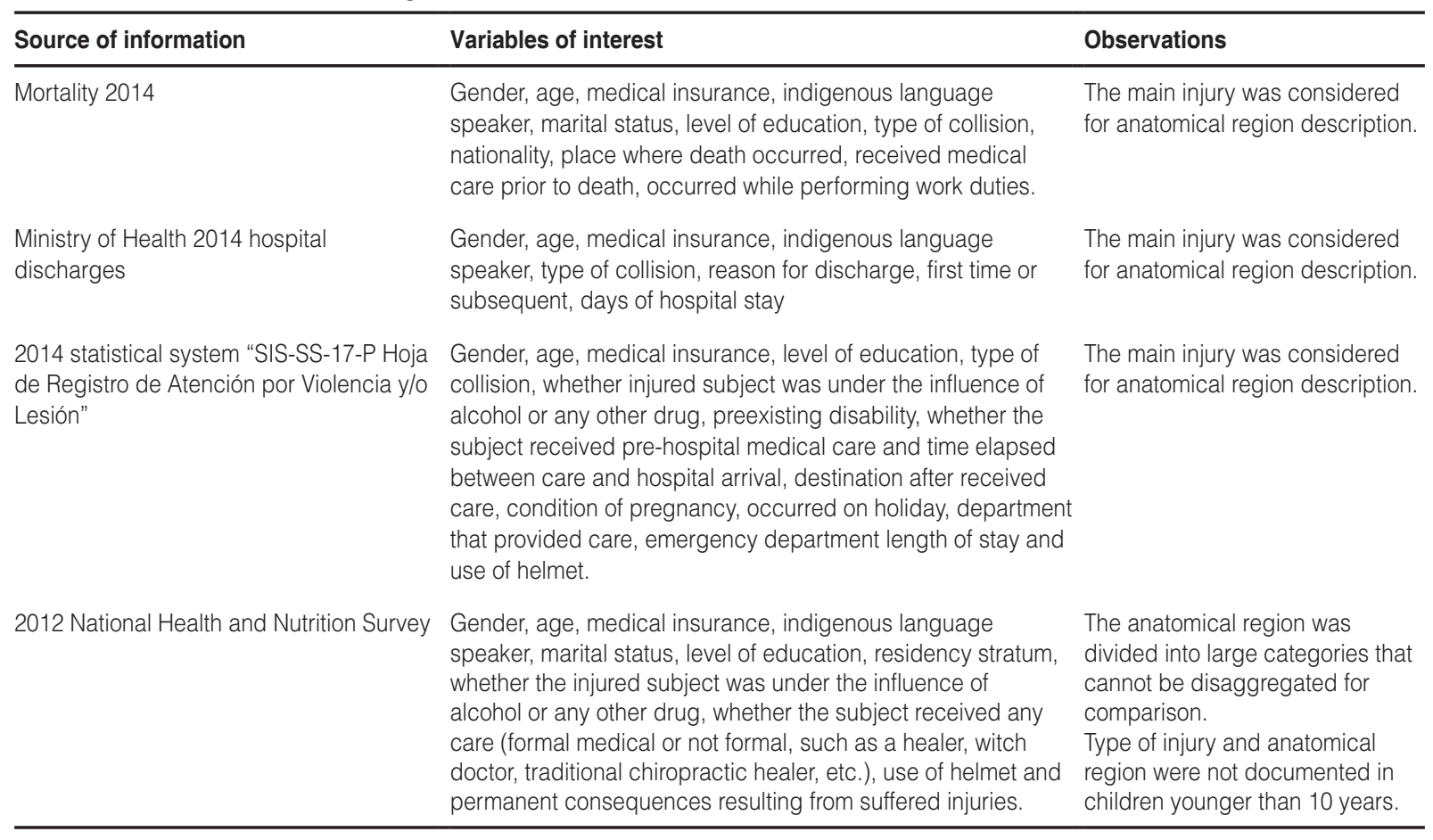


Table 1 shows the useful data available for each source of information. It should be noted that, among these four sources, only ENSANut-2012 and SIS-SS-17 record data on the use of helmet at the moment injuries are suffered. Frequencies and percentages are reported for categorical variables, and means and standard deviations for continuous variables. To assess the relationship between the use of helmet and the presence of head, face and neck injuries, Pearson's chisquare test was used for equality of proportions, with Fisher's exact test being used when expected values were lower than 5 .

Given that a secondary analysis of official databases was performed, without individual identifiers, this study had no risk for any participant, and requesting approval by any ethics committee was therefore not necessary.

\section{Results}

According to the mortality data, 190 cyclists died in the country in 2014 , which accounts for $1.20 \%$ of total people who died due to RTIs in the country. Out of them, only six were females (3.16\%). Average age was 47.67 years (with a standard deviation of 20.51), and most affected age categories were that of 60 years and older and 40 to 49 years with 31.05 and $19.47 \%$ of cases, respectively. Most cyclists died in public roads $(63.16 \%)$ and $28.42 \%$ died in a public medical unit. In this sense, it draws the attention that only $32.11 \%$ of deceased cyclists received some type of medical care before dying. Importantly, in $16.84 \%$ of cases (32 cyclists) the event occurred while performing work-related duties. Table 2 presents more detailed information.

The head was the most commonly affected anatomical region in deceased cyclists, which was reported in $63.16 \%$ of cases. The chest was the second anatomical region in importance, with $12.11 \%$ of cyclists, followed by "multiple regions" with $11.58 \%$ (Table 3). None of the deceased cyclists in 2014 had injuries in the upper limbs, ankles or feet.

2014 data on hospital discharges reveal that there are around two hospitalized cyclists, only in the Ministry of Health, for each person who dies, considering that of the 392 recorded discharges, $95.66 \%$ were after first-time admissions and the rest were after subsequent admissions. Cyclists accounted for $1.49 \%$ of total RTIs. The age group with most hospitalizations was that of 10 to 19 years, with $25.77 \%$, followed by the 20 to 29-year and 30 to 39-year groups, with
$17.35 \%$ and $15.31 \%$, respectively. It can be observed that the vast majority of injured cyclists collided with an automobile or van (59.18\%). Most of wounded subjects were discharged from hospital owing to an improvement $(79.34 \%) ; 7.91 \%$ were referred to other hospital for their care and only 22 injured cyclists died at the hospital. On average, cyclists were hospitalized for 6.33 days (standard deviation of 8.72), with a range of 0 to 74 days' hospital stay, although $32.14 \%$ of patients were hospitalized only one day, $12.50 \%$ two days and $10.46 \%$ three days. The head was also the most affected region in hospitalized individuals, with this being reported in $32.14 \%$ of cases. In little less than $17 \%$ were the knee and leg the most affected region, and in $11.73 \%$ there were "multiple lesions"

According to the analysis of the SIS-SS-17-P Violence or Injury-related Care Registry, there were 667 cases of injured cyclists recorded $(1.53 \%$ of total TRIs), mostly males $(79.91 \%)$, who collided with an automobile or van $(49.73 \%)$. Although age average was 29.73 years (standard deviation of 18.61), adolescents were the most affected group (23.99\%), followed by the $20-29$ years' $(21.59 \%)$ and the 30 to 39 years' groups (15.59\%). A total of 32 cyclists referred having a preexisting disability $(4.80 \%)$, four females between 9 and 59 years of age were pregnant at the moment of collision and one of them suffered an abortion as a consequence.

With regard to exposure to protecting and risk factors, less than $1 \%$ were reported to wear a helmet at the moment of collision (0.75\%). In addition, $10.34 \%$ of cyclists were reported to be under the influence of alcohol and $0.15 \%$ had consumed other drugs. As for medical care, only a low percentage received pre-hospital medical care (23.09\%). Average time elapsed between pre-hospital care initiation and arrival to a hospital unit was 140.93 minutes (standard deviation of 551.08), with a median of 30 minutes and a range of 5 to 5949 minutes or little more than 4 days. On average, the injured spent 119 minutes at the emergency department, practically 2 hours. The emergency department was the main department that provided care to the injured $(88.76 \%)$, followed by hospitalization $(6.60 \%)$ and outpatient care $(3.45 \%)$.

"Multiple regions" was recorded as the most commonly affected anatomical region (26.84\%), followed by the head (23.84\%) and the knee and leg (9.60\%). As shown in table 4, the use of helmet appears not to be associated with the presence of face, skull and neck injuries, although it is important to point out the 
Table 2. Descriptive analysis of cyclists with road traffic injuries in Mexico

\begin{tabular}{|c|c|c|c|c|c|c|c|c|c|}
\hline \multirow[t]{2}{*}{ Variables of interest } & \multicolumn{2}{|c|}{2014 Mortality } & \multicolumn{2}{|c|}{2014 Discharges } & \multicolumn{2}{|c|}{2014 SIS-17 } & \multicolumn{3}{|c|}{ ENSANut-2012 } \\
\hline & $N=190$ & $\%$ & $\mathrm{~N}=392$ & $\%$ & $N=667$ & $\%$ & $N=165,348$ & $\stackrel{\infty}{-}$ & $\%$ \\
\hline \multicolumn{10}{|l|}{ Gender } \\
\hline Male & 184 & 96.84 & 324 & 82.65 & 533 & 79.91 & 143,964 & $\stackrel{2}{2}$ & 87.07 \\
\hline Female & 6 & 3.16 & 68 & 17.35 & 134 & 20.09 & 21,383 & $\frac{\varsigma}{\sigma}$ & 12.93 \\
\hline \multicolumn{10}{|l|}{ Age group } \\
\hline$<10$ years & 5 & 2.63 & 29 & 7.40 & 79 & 11.84 & 11,686 & 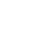 & 7.07 \\
\hline $10-19$ years & 20 & 10.53 & 101 & 25.77 & 160 & 23.99 & 74,133 & (c) & 44.83 \\
\hline 20-29 years & 17 & 8.95 & 68 & 17.35 & 144 & 21.59 & 32,524 & & 19.67 \\
\hline 30-39 years & 19 & 10.00 & 60 & 15.31 & 104 & 15.59 & 14,825 & $\div$ & 8.97 \\
\hline 40-49 years & 37 & 19.47 & 42 & 10.71 & 70 & 10.49 & 11,937 & $\frac{0}{\frac{1}{n}}$ & 7.22 \\
\hline $50-59$ years & 32 & 16.84 & 42 & 10.71 & 51 & 7.65 & 4,974 & $\frac{\bar{O}}{0}$ & 3.01 \\
\hline 60 years and older & 59 & 31.05 & 50 & 12.76 & 59 & 8.85 & 15,270 & $\frac{0}{3}$ & 9.23 \\
\hline Not specified & 1 & 0.53 & & & & & & $\frac{2}{0}$ & \\
\hline \multicolumn{10}{|l|}{ Medical insurance } \\
\hline Not insured & 52 & 27.37 & 98 & 25.00 & 335 & 50.22 & 34,162 & ○ & 20.66 \\
\hline Insured & 111 & 58.42 & 244 & 62.24 & 289 & 43.33 & 131,186 & 으 & 79.34 \\
\hline Not specified & 27 & 14.21 & 50 & 12.76 & 43 & 6.45 & &. $\bar{n}$ & \\
\hline \multicolumn{5}{|l|}{ Speaks indigenous language? } & \multicolumn{2}{|c|}{$N A$} & & $\frac{5}{d}$ & \\
\hline Yes & 19 & 10.00 & 14 & 3.57 & & & 2,968 & 이다 & 1.80 \\
\hline No & 124 & 65.26 & 375 & 95.66 & & & 161,413 & $\frac{\varsigma}{d}$ & 97.62 \\
\hline Not specified & 47 & 24.74 & 3 & 0.77 & & & 967 & : & 0.58 \\
\hline \multicolumn{3}{|l|}{ Marital status } & \multicolumn{2}{|c|}{$N A$} & \multicolumn{2}{|c|}{$N A$} & & 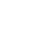 & \\
\hline Single & 47 & 24.74 & & & & & 63,059 & $\frac{1}{2}$ & 38.14 \\
\hline Widowed & 14 & 7.37 & & & & & 3,017 & $\frac{\varrho}{0}$ & 1.82 \\
\hline Separated & 5 & 2.63 & & & & & 5,433 & $\subsetneq$ & 3.29 \\
\hline Divorced & 8 & 4.21 & & & & & 238 & $\rightleftarrows$ & 0.14 \\
\hline Cohabitating & 30 & 15.79 & & & & & 10,759 & 0 & 6.51 \\
\hline Married & 73 & 38.42 & & & & & 40,498 & 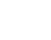 & 24.49 \\
\hline Doesn't apply* & 7 & 3.68 & & & & & 42,343 & 3 & 25.61 \\
\hline Not specified & 6 & 3.16 & & & & & & $\stackrel{\text { 厂 }}{\subseteq}$ & \\
\hline \multicolumn{3}{|l|}{ Level of education } & \multicolumn{2}{|c|}{$N A$} & & & & 응 & \\
\hline Less than primary school & 88 & 46.32 & & & 44 & 6.60 & 58,889 & 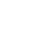 & 35.62 \\
\hline Completed primary school & 49 & 25.79 & & & 265 & 39.73 & 41,044 & $\ddot{\circ}$ & 24.82 \\
\hline Completed secondary school & 31 & 16.32 & & & 196 & 29.39 & 38,838 & $\frac{c}{2}$ & 23.49 \\
\hline Completed high school & 6 & 3.16 & & & 76 & 11.39 & 10,300 & - & 6.23 \\
\hline College or higher & 2 & 1.05 & & & 19 & 2.85 & 11,879 & - & 7.18 \\
\hline Doesn't apply** & 2 & 1.05 & & & 38 & 5.70 & 4,397 & 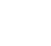 & 2.66 \\
\hline Not specified & 12 & 6.32 & & & 29 & 4.35 & & $\frac{3}{0}$ & \\
\hline \multicolumn{5}{|l|}{ What did the subject collide } & & & \multirow[t]{6}{*}{$N A$} & $\frac{0}{0}$ & \\
\hline with? & 3 & 1.58 & 54 & 13.78 & 85 & 12.74 & & $\div$ & \\
\hline Motorcycle & 68 & 35.79 & 232 & 59.18 & 325 & 48.73 & & $\stackrel{1}{1}$ & \\
\hline Automobile or van & 17 & 8.95 & 33 & 8.42 & 27 & 4.05 & & $\vec{\lambda}$ & \\
\hline Heavy transport or bus & 102 & 53.68 & 73 & 18.62 & 230 & 34.48 & & 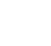 & \\
\hline Not specified & & & & & & & & $\frac{c}{a}$ & \\
\hline
\end{tabular}

*Doesn't apply in children younger than 12 years.

${ }^{*}$ Not recorded in children younger than 6 years.

NA: Not available; SS-17: SIS-SS-17-P: Hoja de Registro de Atención por Violencia y/o Lesión (Registry Form for Violence and/or Injury-related Provided Care).

low number of injured subjects who reported using helmet.

In the ENSANut-2012 data, there were 117 identified cyclists, which when weighted represent 165,348; $12.6 \%$ of total RTI (95\% confidence interval: $9.8-$ $16.2 \%)$. Most of these were males (87.07\%), and adolescents were the most affected age group (44.83\%), followed by those of 20 to 29 years of age (19.67\%). Mean age was 29.26 years, with a $95 \%$ confidence interval of 29.00 to 29.52 . The unweighted sample median was 19 years. According to residence stratus of the injured, $64.60 \%$ live in a metropolis (with 100,000 or more inhabitants), $21.96 \%$ in urban areas (with 100,000 or more and less than 100,000 
Gaceta Médica de México. 2017;153

Table 3. Anatomical region of main injuries in cyclists with road traffic injuries in Mexico

\begin{tabular}{|c|c|c|c|c|c|c|c|c|c|}
\hline \multirow[t]{2}{*}{ Anatomical region } & \multicolumn{2}{|c|}{$\begin{array}{l}2014 \text { Mortality } \\
(\mathrm{N}=190)\end{array}$} & \multicolumn{2}{|c|}{$\begin{array}{l}2014 \text { Discharges } \\
(\mathrm{N}=392)\end{array}$} & \multicolumn{2}{|c|}{$\begin{array}{l}2014 \text { SIS-17 } \\
(\mathrm{N}=667)\end{array}$} & \multicolumn{3}{|c|}{$\begin{array}{l}\text { ENSANut-2012* } \\
(\mathrm{N}=165,348)\end{array}$} \\
\hline & $\mathrm{N}$ & $\%$ & $\mathbf{N}$ & $\%$ & N & $\%$ & $\mathrm{~N}$ & స్ & $\%$ \\
\hline Head & 120 & 63.16 & 126 & 32.14 & 159 & 23.84 & 39,334 & & 23.79 \\
\hline Neck & 3 & 1.58 & 6 & 1.53 & 39 & 5.85 & & $\stackrel{\sigma}{E}$ & \\
\hline Chest & 23 & 12.11 & 9 & 2.30 & 20 & 3.00 & 27,953 & & 16.91 \\
\hline Abdomen, spine and pelvis & 10 & 5.26 & 19 & 4.85 & 20 & 3.00 & & & \\
\hline Shoulder and arm & & & 25 & 6.38 & 38 & 5.70 & 63,462 & & 38.38 \\
\hline Elbow and forearm & & & 24 & 6.12 & 38 & 5.70 & & 0 & \\
\hline Wrist and hand & & & 9 & 2.30 & 25 & 3.75 & 28,639 & & 17.32 \\
\hline Hip and thigh & 1 & 0.53 & 37 & 9.44 & 13 & 1.95 & 64,228 & & 38.84 \\
\hline Knee and leg & 1 & 0.53 & 65 & 16.58 & 64 & 9.60 & & $\frac{0}{c}$ & \\
\hline Ankle and foot & & & 7 & 1.79 & 54 & 8.10 & 29,213 & & 17.67 \\
\hline Multiple regions & 22 & 11.58 & 46 & 11.73 & 179 & 26.84 & $N A$ & $\frac{5}{4}$ & $N A$ \\
\hline Region not specified & 5 & 2.63 & 11 & 2.81 & 16 & 2.40 & 16,917 & & 10.23 \\
\hline Foreign body through natural orifice & 1 & 0.53 & & & & & $N A$ & $\frac{7}{3}$ & $N A$ \\
\hline None (lost value) & 4 & 2.11 & 8 & 2.04 & 2 & 0.30 & 22,921 & & $13.86^{\star *}$ \\
\hline
\end{tabular}

${ }^{*}$ Corresponds to the number of individuals who reported at least one injury on each anatomical region of interest. Since individuals could have multiple injuries, total number does not necessarily correspond to the sum of the columns above and the sum may exceed the number of analyzed cyclists.

${ }^{*}$ Type of lesion and anatomical region was not documented in children younger than 10 years $(\mathrm{N}=11,686)$.

NA: not available; SIS-17: SIS-SS-17-P: Hoja de Registro de Atención por Violencia y/o Lesión (Registry Form for Violence and/or Injury-related Provided Care).

Table 4. Use of helmet and head, neck and face injuries in cyclists with road traffic injuries in Mexico.

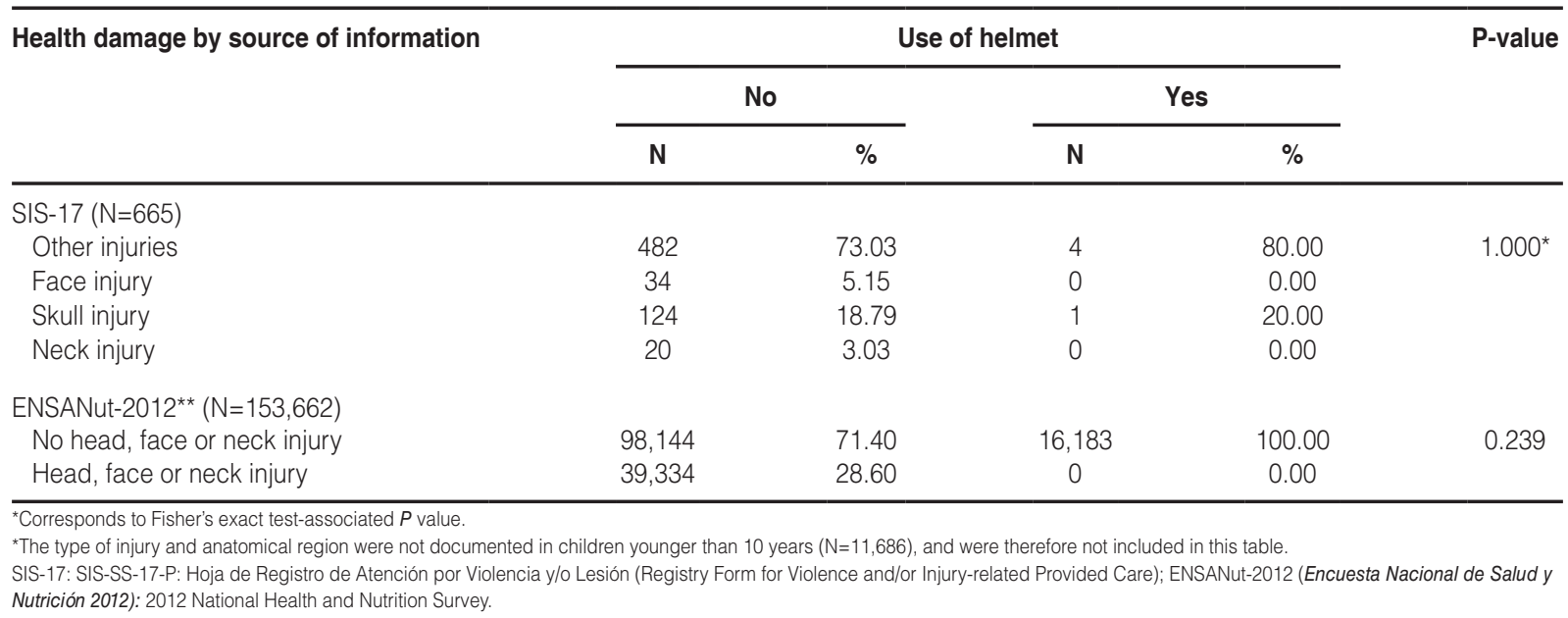

inhabitants), and only $13.44 \%$ in rural areas (less than 2,500 inhabitants).

The analysis of protecting and risk factors shows that, among injured cyclists, only $5.98 \%$ (unweighted) and $9.79 \%$ (weighted) wore a helmet at the moment of getting injured. None of the injured subjects who wore a helmet reported head injuries, as compared with $28.60 \%$ of those who did not wear a helmet, although these differences were not statistically significant, probably influenced by the sample size (Table 4). Among the injured subjects, $7.62 \%$ referred being under the effects of alcohol at the moment of collision. Formal medical care was received by $30.59 \%$ of the injured, $30.07 \%$ were self-medicated, $5.70 \%$ received non-formal care, and $28.97 \%$ did not receive any type of care.

A total of 16,608 cyclists reported permanent sequels on their health status as a consequence of 
RTI's, the majority $(60.81 \%)$ related to limitations or difficulty to move or walk (or requiring help to do it), and $15.35 \%$ refers to limitations or difficulty to use their arms or hands. Permanent consequences are closely related to the most affected anatomical regions: $38.84 \%$ had lower limb, 38.38\% upper limb and $23.79 \%$ head and neck involvement (Table 3).

\section{Discussion}

To our knowledge, this is the first study carried out in Mexico to document the epidemiology of injuries in cyclists, which are among the most vulnerable public road users. In general, it was possible to observe that the head was one of the most compromised anatomical regions in these road users, and the data suggest that this can be related to a worse health outcome. It would appear that the low rate of helmet use, particularly of certified helmets, might have influenced for traumatic brain injury (TBI) being the most common injury among the analyzed cyclists. Although based on the analyzed data the helmet appears not to be associated with a lower incidence of injuries, it is important for three observations to be taken into consideration: 1) the low number of cyclists who reported using a helmet at the moment of injury; 2) there were no injured cyclists who reported any face, head or neck injury in ENSANut-2012; and 3) there was no information available on whether the used helmets were certified or not.

The use of helmet in injured cyclists in Mexico was significantly lower than that previously reported in Alberta or Montreal (Canada), where $26 \%$ of deceased subjects and $25 \%$ of cyclists who sustained TBI, respectively, were wearing it ${ }^{13,14}$. The helmet is an intervention intended for cyclist protection. Two main mechanisms that cause TBI intervene in bicycle collisions: direct contact and acceleration-deceleration, and each mechanism produces different injuries. When a bicycle collision occurs, the cyclist is generally ejected from the vehicle. If the head hits an object, e.g., the floor, the movement of the head comes to a stop, but the brain, which has its own mass, continues to move until it hits the opposite side of the skull. The results of this type of injury are diverse, from a mild TBI to a severe TBI that can cause death ${ }^{2}$. Helmets provide an additional layer to the head and, thereby, they protect from the most serious forms of $\mathrm{TBI}^{2}$, as according to available evidence, the use of bicycle helmets reduces the risk of TBI between 63 and $88 \%{ }^{15}$.
To ensure that helmets effectively prevent skull and face injuries they must meet certain safety standards. There are different types of certification in the world; for example, helmets available in the USA must be certified by the Consumer Products Safety Commission (CPSC, which also endorses the ASTM F1447, F1898, Snell B-90A, B-95 y N-94 certifications) $)^{16}$; in Europe, there are the BS 6863, EN 1078:2012 and EN 1080:2013 certifications; and the New Zealand and Australia certification is known as AS/NZ 2063 ${ }^{17}$. In Mexico there is no certification for bicycle helmet manufacturing and sale; as long as this does not occur, consumers should be advised to check for compliance with any of these certifications when acquiring a bicycle helmet.

There is a debate on whether legislating on mandatory use of helmet, as some authors have suggested $^{18-20}$. It is regarded as an effective measure to increase its use and decrease the number of injuries and deaths in cyclists ${ }^{21}$. Other authors differ about this measure, since it discourages the use of bicycle as a means of transportation ${ }^{22,23}$. While this debate is going on, an important number of cyclists are injured and die in road traffic, and empowering the users of this means of transportation with available evidence is therefore necessary in order for them to know the risks they face and the potential preventive effects of the use of helmet.

However, the promotion of helmet use should not be the only and neither the most important measure to prevent injuries in cyclists. It is but one measure that has to be part of a comprehensive approach to the problem, which should include key elements such as: a) road design should be sensitive to cyclists' spatial needs, which in primary and secondary roads implies the construction of cycle paths in order to separate this user and avoid its contact with motor vehicles $^{7}$; b) decrease of motor vehicles velocity, which can be achieved by means of physical velocity reducers (speed bumps, traffic lights, etc.) or by establishing speed limits and their rigorous enforcement, either directly or by means of the implementation of strategies such as photo-enforced tickets ${ }^{24} ; \mathrm{c}$ ) promotion of bicycle as a means of transportation, since according to some authors, the increase in the number of circulating cyclists is by itself a form to reduce the risk of injury, which is known as "safety in numbers" 25 and d) educational strategies aimed at achieving safer behaviors in all public road users and at the use of safety devices (lights and reflective strips and vests). Here, it would be important to promote 
among cyclists to refrain from using the bicycle under the influence of alcohol or other drugs, since $10 \%$ of the injured captured in SIS-17 and $8 \%$ of ENSANut-2012 injured cyclists referred being under the influence of alcohol, although this level of exposure is lower to that reported in Alberta (Canada), among cyclists dead in road traffic $(25 \%)^{13}$. All these measures, as a whole, might contribute to prevent the high number of fatal and non-fatal injuries in these vulnerable public road users ${ }^{7}$.

On the other hand, the high percentage of cyclists who die in public roads $(63.16 \%)$, mainly without receiving medical care $(89.17 \%)$, reflects the seriousness of the sustained injuries. This highlights the importance of creating the safety conditions required to minimize health damages produced by this means of transportation, since in most reported cases $(77.27 \%)$, collisions were against an automobile or van, at a clear disadvantage. This percentage is significantly higher than that observed in places such as New Zealand, where $26 \%$ of all injuries in cyclists and $39 \%$ of serious injuries in cyclists were the result of collisions against this type of motor vehicles ${ }^{26}$. In this same sense, the low number of injured cyclists covered by pre-hospital medical services (23\%) according to the SIS-17 registry stands out, which altogether is an urgent call for the regulation of this type of care to be improved and for the formation of a Medical Emergency System in the country, which is a still pending task ${ }^{27}$.

This study has several limitations, mostly attributable to the fact that the sources of information used were secondary. On one hand, it is important to point out the need to improve information systems in order to include the systematic collection of data on risk factors and protecting factors to enable decision-making to be informed, and public policies for road safety to be designed, as well as to assess the impact of specific interventions. In this sense, the use of helmet was not documented in $71.21 \%$ of injured cyclists recorded by SIS-17. On the other hand, the ENSANut-2012 design sought national representativeness for events with a prevalence of $10 \%^{28}$. While the prevalence of injured cyclists might be a relatively reliable indicator, the socio-demographic characteristics presented in this work might not be representative for the total of cyclists that suffered non-fatal injuries during 2012 in the country. However, this is the most reliable information so far, particularly because it includes injured individuals not attending health services due to access problems or because their injuries were not serious enough. Useful information, such as helmet certification, was not documented. Hence the need of other methodological approaches to assess if helmets really do not offer protection, whether this is because those that are being used lack certification or if there are other factors that explain this. Additionally the results could be enriched with information on the use of helmet by cyclists by means of the observation of this public road user in different contexts of the country (information that is not available at this moment). This would allow knowing if cyclists who use helmet assume safer behaviors in Mexico or if, conversely, the perception of protection offered by the helmet makes them adopt risky behaviors, just as documented in other contexts ${ }^{29}$.

We can conclude that, although cyclists do not represent a proportionally important group for the moment, the existence of different strategies to incentivize the use of bicycle as a sustainable means of transportation makes it necessary to anticipate in order to prevent the potential effects of these strategies in terms of RTIs. For this, as long as safe roads are not ensured in the mid- and long-term as one of the main factors associated with cyclists' safety, speed-control measures, the use of lights reflecting stripes and vests and particularly the promotion of the use of certified helmets on the short term, should be intensified, since the latter is a measure that is also effective to prevent the main type of injury faced by cyclists: TBI. Since there are no previous analyses integrating all these sources of data, this work will lay the foundations that will allow more detailed analyses to be carried out in order to better understand the health damages associated with this sustainable means of transportation.

\section{Acknowledgements}

The authors would like to thank the team at the ITDP, which contributed to the development of the document More cyclists, safer cyclists: guideline of interventions for the prevention of injuries in cyclists, which through different academic discussions motivated the performance of this study intended to provide evidence for future analyses and new discussions.

\section{Conflicts of interests}

The authors declare not having any conflicts of interests. 


\section{References}

1. World Health Organization. Global Status Report on Road Safety 2015 Geneva, Switzerland: WHO; 2015. Disponible en: http://www.who.int/violence_injury_prevention/road_safety_status/2015/en/.

2. Organización Panamericana de la Salud. Cascos. Manual de seguridad vial para decisores y profesionales. Washington, D.C., EUA: OPS; 2008. Disponible en: http://www.bvsde.paho.org/bvsdevial/fulltext/Cascos/indice.pdf.

3. Sistema de Transporte Individual ECOBICI. Ciudad de México: Secretaría del Medio Ambiente.(Accedido el 20 de mayo de 2016.) Disponible en: https://www.ecobici.df.gob.mx.

4. Sistema de Bici Pública MIBICI. Guadalajara: Secretaría de Movilidad. (Accedido el 20 de mayo de 2016.) Disponible en: https://mibici.net/a-9meses-de-mibici/.

5. SmartBike. Puebla: H. Ayuntamiento de Puebla. (Accedido el 20 de mayo de 2016.) Disponible en: http://www.pueblacapital.gob.mx/noticias/itemlist/category/314-smartbike.

6. Sistema de Bici Pública Huizi. Toluca: H. Ayuntamiento de Toluca. (Accedido el 20 de mayo de 2016.) Disponible en: https://www.facebook. com/BiciPublicaToluca/(ya no hay otra página oficial que anide el sitio, sólo Facebook).

7. Secretaría de Salud/STCONAPRA/ITDP. Más ciclistas, más seguros. Guía de intervenciones para la prevención de lesiones en ciclistas urbanos. Ciudad de México, México; 2016.(Accedido el 20 de mayo de 2016.) Disponible en: https://www.gob.mx/cms/uploads/attachment/ file/83621/M_s_ciclistas_ITDP_final_carta_electr_nico_.pdf.

8. Dirección General de Epidemiología, Secretaría de Salud Federal. Subsistema Epidemiológico y Estadístico de Defunciones (SEED). México, 2014. (Accedido el 20 de mayo de 2016.) Disponible en: http://www.dgis salud.gob.mx/contenidos/basesdedatos/std defunciones gobmx.html.

9. Dirección General de Información en Salud, Secretaría de Salud Federal. Subsistema Automatizado de Egresos Hospitalarios (SAEH).México 2014. (Accedido el 20 de mayo de 2016.) Disponible en: http://www.dgis. salud.gob.mx/contenidos/basesdedatos/std_egresoshospitalarios_gobmx.html.

10. Dirección General de Información en Salud, Secretaría de Salud Federal. Registro de Atención por Violencia y/o Lesión (SIS-17).México; 2014 (Accedido el 20 de mayo de 2016.) Disponible en: http://www.dgis.salud. gob.mx/contenidos/basesdedatos/da_lesiones_gobmx.html.

11. Instituto Nacional de Salud Pública. Encuesta Nacional de Salud y Nutrición 2012. Resultados Nacionales. México; 2012.(Accedido el 20 de mayo de 2016.) Disponible en: http://ensanut.insp.mx/basesdoctos.php\#. V47VavnhBhE.

12. Organización Panamericana de la Salud. Clasificación Estadística Internacional de Enfermedades y Problemas Relacionados con la Salud. Décima revisión. 10. ${ }^{a}$ ed. Washington, DC: OPS; 1995.

13. Gaudet L, Romanow NTR, Nettel-Aguirre A, et al. The epidemiology of fatal cyclists crashes over a 14-year period in Alberta, Canada. BMC Public Health. 2015;15:1142.
14. Dagher JH, Costa C, Lamoureux J, et al. Comparative outcomes of traumatic brain injury form biking accidents with or without helmet use. Can J Neurol Sci. 2016;43:56-64.

15. Peden MM, Scurfield R, Mohan D, et al, editores. World report on road traffic injury prevention. Geneva: World Health Organization; 2004.(Accedido el 20 de mayo de 2016.)Disponible en: http://www. who.int/violence_injury_prevention/publications/road_traffic/world_report/en/.

16. Consumer Products Safety Comission. EUA: Which helmet for which activity?(Accedido el 20 de mayo de 2016.)Disponible en: https://www. cpsc.gov/safety-education/safety-guides/sports-fitness-and-recreation-bicycles/which-helmet-which-activity.

17. Product Safety Australia.Australia: Bicycle helmets. (Accedido el 20 de mayo de 2016.)Disponible en: http://www.productsafety.gov.au/content/ index.phtml/tag/bicyclehelmets.

18. Walter SR, Oliver J, Churches T, et al. The impact of compulsory helmet legislation on cyclist head injuries in New South Wales, Australia: aresponse. Accid Anal Prev. 2013;52:204-9.

19. Macpherson A, Spinks A.Bicycle helmet legislation for the uptake of helmet use and prevention of head injuries. Cochrane Database Syst Rev. 2008;(3):CD005401.

20. Karkhaneh M, Kalenga JC, Hagel BE, et al.Effectiveness of bicycle helmet legislation to increase helmet use: a systematic review. Inj Prev.2006;12:76-82.

21. Persaud N, Coleman E, Zwolakowski D, et al.Nonuse of bicycle helmets and risk fatal head injury: a proportional mortality, case-control study. CMAJ. 2012;184:E921-3.

22. Robinson DL. No clear evidence from countries that have enforced the wearing of helmets. BMJ. 2006;332:722-5.

23. Cycling UK.Cycle helmets: an overview of the evidence. London: Cycling UK; 2016.(Accedido el 20 de julio de 2016.) Disponible en: http://www. cyclinguk.org/sites/default/files/file_public/helmets-evidencebrf.pdf.

24. Elvik R. Quantified road safety targets: an assessment of evaluation. Oslo: Institute of Transport Economics; 2001 Oct. TØI Report 539/2001. (Accedido el 20 de julio de 2016.)Disponible en: https://www.toi.no/getfile.php?mmfileid=17511.

25. Jacobsen PL.Safety in numbers: more walkers and bicyclists, safer walking and bicycling. Inj Prev. 2003;9:205-9.

26. Tin-Tin S, Woodward A, Ameratunga S. Injuries to pedal cyclists on New Zealand roads, 1988-2007. BMC Public Health. 2010;10:655.

27. NORMA Oficial Mexicana NOM-034-SSA3-2013, Regulación de los servicios de salud. Atención médica prehospitalaria. Diario Oficial de la Federación. Órgano del Gobierno Constitucional de los Estados Unidos Mexicanos, 23 de septiembre 2014; número 17, sección I, Tomo DCCXXXII.(Accedido el 20 de mayo de 2016.) Disponible en: http://dof.gob. $\mathrm{mx} /$ nota_detalle.php?codigo=5361072\&fecha=23/09/2014.

28. Romero-Martínez M, Shamah-Levy T, Franco-Núñez A, et al. Encuesta Nacional de Salud y Nutrición 2012:diseño y cobertura. Salud Publica Mex. 2013;55(Supl 2):S332-40.

29. Gamble T, Walker I. Wearing a bicycle helmet can increase risk taking and sensation seeking in adults. Psychol Sci. 2016;27:289-94. 